23pPS2

(特別講演)

レーザー学会学術講演会第17回年次大会

\title{
レーザー物理学の今後への期待 \\ Expectation of Further Progress in Laser Physics
}

宅間 宏（日本原子力研究所・関西研究所）

Hiroshi Takuma, JAERI Kansai Research Establishement

1.レーザーの性能の向上とレーザー物理学

ルビーレーザーが初めて発振した 1960 年以来，レーザーの性能は絶えず向上しまた それに伴って次々に新しい領域が拡大されつつ今日に至っている。以来 36年を経過した現 在でも, レーザーの種類と性能はさらに進歩し続けている。このような果てしないレーザー 技術の発展が今後も引き続き活発に行われるならば，その周辺に常に新しい領域が生まれ発 展し続けることが期待される。したがって，このような発展を正確に予測するためには，具 体的にレーザーのどのような性能がどの程度向上する可能性があり，またその結果新技術が どれほどの向上を示すのか, 定量的な検討が行われなければならない。

このようなレーザー性能の新領域への発展は, 新しい性能の発展が広義の物質と光の相 互作用においてどのような新局面が展開され得るかを，広い視野で理諭的に考えることによ り予测することができる。この際, 新しい領域が必ずしも従来の路線の延長上に在るとは限 らないという認識が重要である。

また一方において，技術の動向を見極めることが基碟科学の将来を推し量る上で極めて 重要である。事実,レーザーは「基礎と応用は相互に強く影響し合いながら発展する」とい う古典的な教訓をもっとも端的に証明したものの一つと思われる。技術のニーズによって開 拓された技術が新しい学術的な発展の可能性を与えることも，将来を見極める上で極めて重 要な要素である。以下にレーザー性能に関して今後の向上の可能性があり得るか, それに伴っ てどのような新領域が展開され得るかを偏見の入ることをあえて恐れずに概観してみよう。

2.レーザーのピーク出力の增大

現在新分野を開拓しつつあるレーザー技術の新展開の一つは，極短パルス化と超高出力 化である。従来の進歩の中で, レーザー出力の增大は, その都度新しい領域の発展を促して きた。しかし, 現在の進展は, 過去において考えられなかったほどの高照射密度を可能とす るので，原子に含まれる電子を急速に次々と電離してついには原子核をほとんど裸にしてし まうなど，新しい物理現象が関与し始める。しかも，極短パルス化することによって，ピー ク出力は高くてもパルスの出力エネルギーは比較的小さいので, 比較的コンパクトなレーザー システムによってそれが達成されることが素晴らしい。実際に高品質のビームとして, 10 $\mathrm{TW}$ 以上の出力を得ることができる。このような超高出力光を集光することよって $10^{19} \mathrm{TW}$ $1 \mathrm{~cm}^{2}$ を超える超高光電磁場発生することが可能となった。

今後の展開は, $100 \mathrm{TW}$ から $1 \mathrm{PW}$ を目標に展開されるが, すでに $1 \mathrm{PW}$ を超えて EWに 向かう新しいコンセプトによる研究も始まっている。

このような超強光電場によって, 電界電離による多価イオンの生成や, ポンデラモーティ ブカによるプラズマ密度分布形成による自己収束効果など, 新しい物理現象が観測されてえ いる。またこれらの新現象を利用することにより，際結合型のX線レーザーなどが試みられ， 


\section{レーザー学会学術講演会第17回年次大会}

興味ある成果が得られている。さらに最近では，20 TW 超える超高出力光を集光すること よって $10^{19} \mathrm{TW} / \mathrm{cm}^{2}$ を超える超高光電磁場が作られ，電子の相対論的効果が顕著になり，相 対論的効果による自己収束などの新しい現象が観測されはじめている。

さらに, 電子ビームと超高出力光との逆コンプトン散乱によって波長可変ガンマ線の発 生, さらにそのようにして発生したガンマ線と超高出力パルス光との衝突による光子一光子 散乱の研究が行われ，ポジトロンの発生が確認されている。

このような波長可変ガンマ線は原子核の分光的研究の新しい手段を提供するが，ピーク 出力の更なる向上によって，原子核に直接光子が作用する非線型光学的な新現象の観測など も期待される。

このような超強光電場の影響の他に，超短時間のエネルギー集中によって，超短パルス と物質との相互作用はピコ秒以上の場合に比べると極めて単純化され，殆ど電子の加熱だけ が行われる。それ故に物質との相互作用は優れた再現性を持ち，たとえば生態の切り口も鋭 くきれいになることが知られてえいる。このような特徵は, 電子のみをマニピュレートする のに便利と思われる。たとえばレーザー加速において，単に超強光電場で巨大な加速度が発 生できるだけでなく，特定の電子だけを取り出す工夫などにこの特徴をうまく利用すること も可能であろう。

3.X線レーザー

エックス線レーザーに関しては，現在いろいろな見方があるのは事実である。現在まで に実現されている，多価イオン原子によるエックス線レーザーの方式は，電子衝突励起型と 再結合型とに大きく二つに分けることができる。前者の方式については，核融合用の超大型 レーザーを用いて実験的な研究が行われ，理論的な解析や関連する原子物理学的なデー夕も かなり揃ってはいるが，後者についての成功例は未だに少ない。しかしいわゆるТキューブ・ レーザーによるX線レーザーとして，特に短波長に向けて水素型やリチウム型の再結合型レー ザーは興味があり, 今後の活発な研究が期待される。

再結合型のレーザーには，光電界による電離によって原子核を殆ど裸にする過程と，そ れが周囲の電子と再結合して励起状態の水素型, リチウム型などのイオンを作る再結合過程 とが必要で，極めて少ない成功例である緑川ら（理研）の方法で示されたように，再結合が エックス線の放射より急速に行われるためには多価イオンを低温の電子が取り巻く環境を作 る工夫が成功の鍵となる。たとえば，原研の永島らは水素とネオン，爫素などの混合気体を 用いる効率的な再結合型レーザーを提案した。今後の基礎研究の積み重ねによって, 実験条 件に合致するモデルの構築と有効なデータの蓄積の結果, 最適化条件を整えて効率の向上が 期待されるとともに，この方式でどこまで行けるかが明らかになろう。

その他の方式としては, 原理的には内款励起型のレーザーがあり得る。従来他の方法で 発生した短波長のエックス線による励起方式が提案されたが，実験的にはそう簡単ではない。 内殻電子が電離すれば，直ちに反転分布となるので，確かに反転分布を作る効率的な方法と 言えようが，オージェ過程など，競合する過程に打ち勝って素早くX線光子の放射が起きて しまうことが必要である。したがって，系の選択とエックス線レーザーの設計が鍵となる。 


\section{レーザー学会学術講演会第17回年次大会}

\section{Tキューブ・レーザーと原子核物理学}

原子核を構成する要素は, 中性子と陽子なので, 電磁場との相互作用の影響は極めて小 さい。原子核のサイズが原子に比べて著しく小さい。相互作用もそれに比例して（高次の相 互作用はその赛上に比例して）小さい上に，陽子は質量が大きいからである。それでも照射 強度が十分高くなれば, 高次の相互作用によってレーザーによる原子核の直接の可能性があ る。加速された電子と $\mathrm{T}$ キューブ・レーザー出力との逆コンプトン散乱によって，ガンマ線 を発生することができる。このような $\gamma$ 線は波長可変であって, 高分解能の核分光学が可能 となる。その結果, 原子核の構造がより詳しく理解され，将来原子核の変換などに応用する 可能性も出てくるものと考えられる。

\section{5. 超高時間分解能}

現在もっとも短い時間の発生はいわゆるフェムト秒レーザーによって達成されている。 化学反応の制御の可能性も長期にわたって世界記録であった $6 \mathrm{fs}$ の記録は最近になってやっ と破られたが, 現在波一つの光の発生, すなわち $1 \mathrm{fs}$ 程度の短時間に一方向のみを向く超短 パルスの発生とその影䅉が真剣に議論されはじめている。このような光は, 単に短い時間作 用するだけでなく, 一方向のみ作用する点でも特別な意味を持ち, 交流では打ち消される効 果もあらわに出ることになるので，その応用についての夢は尽きない。

6. 単色性, 周波数安定性

レーザー性能のもう一つの重要な条件は単色性と周波数安定性である。超高分解能分光 学は既に完済された領域と言えるかも知れないが，その応用によって新しい領域が開拓され ている。その一つが原子のレーザー冷却であり, その結果を応用した原子光学とボーズ・ア インシュタイン凝縮気体の発生である。まず1995年夏に J I L A でルビジムによる成功が 伝えられ，続いてMI Tでナトリウム，ライス大学でリチウムについての成功が伝えられた。 M I Tでは，レーザーでB ECを二つに分ける手法を活かして，BE Cの衝突実験に成功し， 応用研究が一歩前進した感がある。今後 B E Cがどのような応用上の意義を持つかは B E C 理想気体とは何かを十分に考えれば自ずから明らかになろう。

レーザー分光学などの基礎が確立された現在，その応用によってどのような可能性があ るかが, 物理学的な研究の発展についても考慮されなければならない。分光学の基礎物理学 への応用の一つとして，対称性の破れに関する実験的検証が一例として上げられる。さらに， 基礎物理学とレーザーとの関係として, 原子光学は, 量子力学の最も基本的な観測の概念の 直接的可梘化としても重要な意味を持っている。

7.おわりに

以上は多様な発展を遂げつつあるレーザーの物理学への応用の一面に過ざない。今後も 新しい工夫や新しい物質の発見によってレーザーの性能が新たな飛躍が行われる可能性は大 いにあると考えられる。レーザー性能の理論的限界に迫る発展を期待しつつその応用による 新しい物理学の可能性を今後も検討し続けて行くことが必要であろう。 